This is the final peer-reviewed accepted manuscript of:

Debora Mantovani, Giancarlo Gasperoni and Marco Albertini, Higher education beliefs and intentions among immigrant-origin students in Italy, "Ethnicities" (ISSN 1468-7968), special issue on "Educational Inequality, Overcoming Disadvantage", guest edited by Nabil Khattab, XVIII, n. 4, 2018, pp. $603-626$

The final published version is available online at:

doi-org/10.1177/1468796818777549

Rights / License:

The terms and conditions for the reuse of this version of the manuscript are specified in the publishing policy. For all terms of use and more information see the publisher's website.

This item was downloaded from IRIS Università di Bologna (https://cris.unibo.it/)

When citing, please refer to the published version. 


\title{
Higher Education Beliefs and Intentions among Immigrant-Origin Students in Italy*
}

\begin{abstract}
The article addresses beliefs about higher education and ensuing intentions among a large sample of upper secondary school-leavers in Italy, with a focus on children of immigrants. 'Foreign' students currently account for 7\% of upper secondary students, and their incidence has been growing over time. Only a minority of non-Italian students continue their studies at the university level, versus a majority of Italians. The article investigates the extent to which students of non-Italian origin differ from their native fellow students in terms of characteristics associated with a higher likelihood of enrolling in tertiary education The study draws from a survey involving over 5,600 last-year upper secondary students 525 of whom are of immigrant origin - in Italy during the 2013/14 school year. After a brief overview of the evolution and current situation of first and second generations in Italian upper secondary schooling, the text describes similarities and differences between native and non-native students with regard to a set of key features. An exploration of school-leavers' beliefs about the benefits of higher education and its link to the labour market reveals that immigrant-origin students have slightly less favourable views of higher education with respect to their Italian schoolmates. Finally, the analysis turns to schoolleavers' intentions to enrol at university, which is examined via a set of binomial regression models, which suggest that immigrant-origin youths' weaker higher education intentions are largely due to prior decisions in favour of non-academic school tracks.
\end{abstract}




\section{Immigrant-Origin Youths and Higher Education}

In many Western societies, youths belonging to first and second-generation (G1 and G2) immigrant groups display a comparatively low propensity to engage in higher education. This puts them at a disadvantage throughout their life courses, but also entails extensive social costs for the wider population. Some barriers to immigrant-origin students' transition to university are 'hard' and general in nature, mainly linked to social origins. Youths belonging to lower social classes have inadequate access to financial resources, and those from families with low cultural capital (eg, poorly educated parents) tend to perform less well in school and have modest educational aspirations (Bottani, 1986; Gambetta, 1987; Gasperoni, 1996; Breen and Goldthorpe, 1997; Ballarino and Checchi, 2006); in many contexts (children of) immigrants are plagued disproportionately by both factors.

Other more specific, 'soft', obstacles pertain to students' immigrant-origin status. For example, even when they are well-educated, immigrant parents may have a limited proficiency in the destination country's language and insufficient knowledge of the education system (Kristen and Granato, 2007; Vargas, 2004), inhibiting their ability to help children do homework and interact with teachers. Also, students born in the host country (or arrived before school age) are more fluent in the local language, whereas students born and raised abroad are likely to struggle. Thus, G2 students tend to outperform G1s (Portes 
and Hao, 2002; Alba, 2004; Portes and Rumbaut, 2006). Educational performance is also positively associated with convergence of languages spoken at home and at school (OECD, 2006). Family constraints and poor school performance may encourage immigrant-origin youths to drop out of school after compulsory education ends or attend vocational tracks (featuring practical, job-oriented subjects), thus depressing propensity towards tertiary education.

Regardless of their education levels and financial resources, immigrant parents and their offspring often show higher educational aspirations than their native peers (Kao e Tienda, 1995, 1998; Brinbaum and Cebolla-Boado, 2007). Immigrant parents are generally aware of university degrees' economic and social benefits, which allow their children to compete on the labour market, earn higher incomes, increase their chances of upward social mobility, and enjoy greater prestige and status (Bowen, 1997). Furthermore, children’s academic success may represent an opportunity for redemption, a form of compensation for the costs of migration, even the primary goal of migratory projects (Vallet and Caille, 1999; Portes and Rumbaut, 2001a; Kristen et al., 2008). Finally, attitudes towards investment in education may be ethnically linked: the importance placed on education varies among nationalities and cultures (Caplan et al., 1991; Rumbaut, 1994, 1997; Albertini et al., 2018). 
Although immigrant-origin youths face many challenges in attaining an advanced level of education, many do accomplish the task, thus successfully undergoing a process of social selection. Indeed, due to differential selection (Mare 1980) socio-economically advantaged students may be more likely to perform well at school and participate in higher education and thus be over-represented in the latter. Socio-economic conditions are also positively associated to students' unobserved features, such as abilities, motivations and aspirations. Since, at any educational transition point, less-motivated and -skilled individuals are progressively expelled, those who complete upper secondary schooling tend to resemble each other in terms of unobserved characteristics, regardless of their social origins. It seems reasonable that such a differential selection and the ensuing homogeneity among students should apply to immigrant-origin youths as well. In other words, one should expect that G1 and G2 school-leavers are at least as motivated and competent as their native peers, and that social and immigrant origins exert a relatively weak effect on the decision to pursue higher education.

Immigrant-origin students' transition to higher education in Italy receives scant attention. In this article we wish to address this topic and examine the intentions to seek a university education in a sample of upper secondary school-leavers. The text is organised as follows: in Section 2 we will provide some basic information concerning foreign-origin 
students in the Italian school system, further justifying our interest in school-leavers. Next, after providing more detailed information about data and method (Section 3), we ascertain to what extent natives and immigrant-origin youths resemble each other in terms of social origins, past school performance and support for learning provided by families and peers (Section 4) and attitudes towards higher education and the labour market (Section 5).

If the differential selection process is applicable to immigrant-origin youths, we would expect to find a substantial degree of homogeneity among native and immigrantorigin youths. This expectation will be explored in more detail in Section 6, which develops a set of incremental regression models attempting to account for higher education intentions among school-leavers. Our main explanatory variables will be current school track and Italian/immigrant status. Even after controlling for the variables discussed in Sections 4, 5 and 6, we expect school track to remain an important influence on higher education intentions and Italian/immigrant status to play an insignificant role.

\section{Immigrant-Origin Students in the Italian Education System}

In Italy compulsory education - free and accessible to all, regardless of citizenship and legal status - corresponds to primary and lower secondary (lasting, respectively, 5 and 3 years), has a comprehensive, non-selective nature, and features a largely common 
curriculum across the nation. Non-Italians are concentrated in these lower levels of schooling - in the 2013/14 school year more than 450,000 non-Italian citizens $(9.9 \%$ of the total) were enrolled in primary and lower secondary schools - and, reflecting the general immigrant population's distribution, in the economically developed regions of the North. Upper secondary education, lasting five years, is split among three major tracks: academic (liceo), technical (tecnico) and vocational (professionale). ${ }^{1}$ Academic schools have six major subtracks: humanities (featuring classical studies: Latin, ancient Greek, philosophy), science (Latin, philosophy, mathematics, various science subjects, computer science), foreign languages, human sciences (pedagogy, anthropology, psychology, sociology), arts, music and dance. Technical schools feature two major categories economics, technology - and are further divided into 11 subtracks. Vocational schools also have two major categories - industry and crafts, service - which are further divided into six subtracks.

Lower secondary school-leavers are free to enrol in any upper secondary track, yet their choices historically reflect a certain degree of social segregation: upper class children typically enrol in academic track schools (which play a university-preparatory role), whereas less socially advantaged students tend to enrol in technical and, especially, vocational institutes (Gasperoni 1996; 2008), deemed less socially prestigious and more 
geared to providing immediately job-relevant skills. ${ }^{2}$ Upper secondary education hosted over 180,000 foreign-origin students in 2013/14 (6.8\% of the total). Non-Italian students have reinforced segregation patterns, for they are concentrated in vocational and, to a lesser degree, technical schools (12.6 and 8.1\%, respectively, of all students) and shy away from licei (only 3.7\%), although this tendency appears to be weakening among G2s (Bertozzi 2016; Dalla Zuanna et al. 2009).

Completion of any upper secondary education track grants access to any type of higher education. Nevertheless, major tracks predictably feature differing rates of transition to higher education. Students leaving a liceo are extremely likely to pursue a university career (90\%), whereas only minorities of their peers enrolled in technical (40\%) and vocational (20\%) institutes do so (Vergolini and Vlach 2017). Official statistics state that only $33 \%$ of non-Italian upper secondary school-leavers continue studying at the university level, against 50\% of their Italian peers (MIUR 2015). Nonetheless, foreign students from technical and vocational schools are more likely to enter higher education than their Italian peers (respectively, 32 and 14\% against 31 and 11\%), suggesting that among immigrantorigin students upper secondary school choice may be less linked to university aspirations than among Italians. This does not erase the immigrant-native gap, which persists in higher 
education: foreign second-year university students are more likely to drop out than Italians (15 and 10\%, respectively: Lagomarsino and Ravecca 2014).

Throughout their school careers, children of immigrants experience systematic disadvantages with respect to native students. Grade repetition is higher among foreign students and more widespread at higher education levels $(1.4,7.5$ and $12.8 \%$, respectively, in primary, lower secondary and upper secondary school). Immigrant-origin students are more likely to encounter risks of schooling delay (34\%, against $11 \%$ among Italians: Bertozzi 2016), and these risks increase as education levels rise from primary to lower secondary, to upper secondary schools $(13,39$ and $63 \%$, respectively). Schooling delay is not determined merely by grade repetition. Formally discouraged by ministerial guide-lines, Italian schools tend to place foreign students in lower grades than those appropriate for their ages, in order to promote Italian language acquisition, especially among immigrants arriving at greater ages (Mantovani 2008; Mantovani and Martini 2008). Immigrant-origin students earn lower marks in their oral and written exams, and their weaker academic performance is confirmed by standardised test scores achieved in national and international studies, even after controlling for socio-economic and cultural background (Mantovani 2008; Di Bartolomeo 2011; Azzolini et al. 2012; Azzolini 2014; Barabanti 2016). 
Schooling delay, grade retention and poor academic performance lead to a higher risk

of dropping out among children of immigrants in upper secondary education (completion of which is not mandatory in Italy) (Bertozzi 2016). Italy has the highest percentage of foreign early school-leavers in Europe (35\%). Non-Italians account for 9\% of all first-year upper secondary students, but the corresponding share falls considerably in each of the following years, dropping to a mere $5 \%$ among fifth-year students; one can infer that foreign-origin students undergo more intense selection pressures than Italians. ${ }^{3}$

\section{Data and Method}

Our study stems from a research project centred on information barriers and patterns of participation in higher education. We take advantage of the opportunity offered by that project in order to pursue cognitive goals relating to immigrant-origin youths. ${ }^{4}$ More specifically, the data examined here were collected in 44 upper secondary schools, randomly drawn from all such public schools located in three Northern Italian provinces (Milan, Vicenza, and Bologna) and referring to over 5,600 last-year students. The sample was proportionally stratified by school track and representative of last-year students in the above-mentioned provinces' schools. Between October 2013 and January 2014, a semistructured, pencil-and-paper questionnaire was administered to final-year students attending 
the sampled schools (with a completion rate of 99\%) and is the source of the data used here. $^{5}$

Although our study provides a unique opportunity for exploring the higher education intentions of youths on the verge of completing upper secondary education, it also features some limits: the three provinces we take into account cannot be considered fully representative at the national level $;{ }^{6}$ despite the comparatively large sample size, subsamples concerning immigrant-origin youths are less substantial and also do not allow us to explore the potential effects of students' areas of origin (see additional remarks at the end of this section).

Italian/immigrant status is one of the explanatory variables featured in the regression models developed in Section 6. The sociological literature provides no solid consensus concerning the classification of foreign-origin youths. As regards non-Italian students in the Italian context, the legal criterion used by educational institutions focuses on citizenship status. Schools and official statistics define as 'foreign' all students with non-Italian citizenship, regardless of migratory experience. Rather than using a citizenship-based item and risking a high incidence of non-response or low-quality data, we asked students to report their (and their parents') countries of birth. Respondents were classified as 'Italian' if they and both their parents were born in Italy ( $90.7 \%$ of the sample); as 'immigrant-origin' 
if, regardless of respondents' place of birth, both parents were born abroad. The latter were then assigned to G2 (4.2\%) if they were born in Italy or migrated there up to age 5 and to G1 if they arrived in Italy at age 6 or afterwards (5.1\%). G1s and G2s have a higher mean age (19.3 and 18.6) than Italians (18.3), due to the fact that immigrant-origin students have a higher likelihood of being held back and repeating at least one school year, and/or of being enrolled in a class/year that is lower than the one that usually corresponds to their age (Mantovani 2011).

Table 1 illustrates students' main socio-demographic characteristics, broken down by immigrant/Italian status. There are appreciable differences among the three groups in regard to upper secondary school track attended and the underlying social segregation processes. Young Italians are far more numerous in academic track and comparatively few in the vocational track; G2s are equally distributed among the academic, technical and vocational tracks and outnumber G1s in the academic track; G1s display a stronger presence in non-academic tracks. Immigrant-origin youths (with no appreciable difference between G1s and G2s), even when they do opt for an academic track, tend to avoid the more socially prestigious and demanding humanities subtrack (liceo classico). So, on the whole, Italians, G2s and G1s express different profiles in terms of upper secondary education choices, which will be the second explanatory variable used in Section 6's 
regression models. The other variables listed in Table 1 (except area of origin) will be included in the models as control variables.

\section{[Table 1 here]}

The three groups resemble each other in terms of gender composition. Parents' occupational class $^{7}$ underlines a stark contrast as regards native and non-native families' access to material resources. The majority of immigrant-origin youths' parents belong to the working class, against one-fifth of Italians'. Conversely, only a small minority of G1s and G2s (about one-fifth) can count on parents belonging to the white-collar middle or upper class, against the majority of Italians.

Parents' educational qualifications positively affect children's interest, commitment and attainment and are a proxy for the cultural capital that benefits youths' learning experiences. In our sample Italian and immigrant-origin families do not feature appreciable differences relating to the cultural resources they make available to their children: immigrant families have a higher likelihood of featuring both a low level of education (at most a vocational qualification) and tertiary credentials. In fact, the share of families with a university degree is higher in the G2 and G1 groups than among Italian families, which reflects the selection faced by immigrant-origin youths: perhaps G1s and G2s with highlyeducated parents 'survive' more easily until the end of secondary education. ${ }^{8}$ 
Young immigrants' area of origin is of importance for their integration into the host society (Rumbaut 1994; 1997; Rea et al. 1999; Portes and Rumbaut 2001a; 2001b), for such origins are associated with distinct lifestyles, cultures and modes of interaction with the host territory. In our sample, area of origin and timing of migratory experiences are indeed linked. Predictably, G2s feature areas and countries with a long-standing migratory tradition towards Italy: the African continent and, in particular, Morocco; relatively few G2s hail from Eastern Europe and Central and South America, in that sizeable migration flows from these countries are more recent. ${ }^{9}$ Conversely, among G1s we find a higher incidence of young immigrants from Eastern Europe (especially Romania). This variable will not be discussed in the following sections, due to sample size constraints; but, obviously, any differences between G1s and G2s may be linked to their respective associations with 'old' and 'new' migratory flows and origins.

\section{Academic Performance and Climate of Support}

Immigrant-origin students achieve appreciably lower evaluations in their lowersecondary school-leaving exams, as shown by the share of respondents who state that they attained one of the two highest evaluation categories (Table 2). G2s, with respect to G1s, do not seem to enjoy any advantage arising from the fact that they have experienced all their 
schooling in the host society. The share of students who have been held back at least once during their school careers is only $22 \%$ among Italians, but rises to 39 and $42 \%$, respectively, among G1s and G2s (Table 2, second panel). So immigrant-origin schoolleavers, despite having survived selection mechanisms, continue to display relatively weaker school careers.

The mean marks reported by respondents for two basic subjects (Maths and Italian) over the year prior to the survey exhibit a substantial equivalence across groups (except, unsurprisingly, for the slightly weaker performance of G1s in Italian). These findings point to an overall alignment, over the duration of upper secondary schooling, of groups' academic performance. However, the use of such judgments as a proxy for academic achievement is not without problems: examiners may be more lenient towards students of immigrant origin and more likely to attribute their (especially G1s') shortcomings to a lack of knowledge of Italian rather than inadequate commitment or competence (MIUR 2005; 2008).

\section{[Table 2 here]}

Students' actual academic efforts were operationalised via a self-reported estimate of the number of hours devoted to study on a daily basis. G1s and G2s are less likely to spend 
more than 2 hours on schoolwork than their Italian peers, but this might be partly due to the fact that school tracks place different demands on their students.

Italians and immigrant-origin respondents express similar levels of learning aptitude and pleasure in attending school, with slightly stronger self-images among G1s; the last panel in Table 2 refers to a school self-image index combining the two items and that will be used in Section 6.

Students' likelihood to engage in tertiary education may be linked to other features of their family and friendship contexts. G1s and G2s are less likely than Italians to be asked by their parents about their school day, receive assistance from them in addressing problems at school and talk with them about their post-diploma future (Table 3; the final panel refers to a parental support index combining the three items and that will be used in Section 6). Similar findings are reported in other Italian studies and are attributed typically to immigrant parents' lack of language proficiency, time constraints due to job commitments, and lack of comfortable spaces at home for schoolwork (Casacchia et al. 2008; Dalla Zuanna et al. 2009). So, even though among immigrant-origin youths there is a comparatively high share of well-educated parents, the latter on the whole do not engage often with their children about their education. 
This lack of knowledge extends to higher education: respondents' family members and friends, especially among G1s and G2s, tend not to be a useful source of information for tertiary studies (Table 4, items b and c); also, immigrant-origin youths are less likely to have friends contemplating university studies (item a). Despite this context of cognitive and experiential deprivation, immigrant-origin parents, with respect to their Italian equivalents, exert more pressure on their children as regards the pursuit of educational credentials (item d), thus seemingly confirming that children's educational attainment is a key migration goal (Albertini et al., 2018). The final panels in Table 4 refer to indexes that will be used in Section 6 and that combine, respectively, the items involving friends' and parents' support for higher education.

[Table 3 here]

[Table 4 here]

\section{Beliefs Concerning Higher Education and Related Job Prospects}

Upper secondary education school-leavers' perceptions of the relationship between tertiary education and the labour market were explored with a battery of 11 items listed (in descending order of overall endorsement) in Table 5. Only one item, highlighting the cultural enrichment associated with university studies, enjoys a very high level of support. 
Other items espoused (ie, scored 6 or higher) by a majority of respondents concern the importance of personal contacts (over a university degree) for finding a well-paying job, the difficulty of university studies, the greater job opportunities enjoyed by university graduates, and the role of luck in finding a good job. All remaining items - most of which express unfavourable opinions about higher education - are rejected (ie, scored 5 or lower) by a majority of respondents.

\section{[Table 5 here]}

Items displaying statistically significantly different levels of approval among Italians and immigrant-origin youths point, above all, to the latter's greater sensitivity to cost considerations. 'Studying at university would be too expensive (item h) is approved among G2s and, in particular, G1s to a greater degree than among Italians. 'In deciding whether to enrol at university, tuition fees aren't important' (item j) gives rise to comparable results: G1s are more sensitive towards cost issues. Similarly, G2s and G1s are more likely to believe that higher educational commitments entail a significant delay in income-earning (item f). Immigrant-origin youths' comparatively greater concern for cost issues possibly reflects their lower social class origins and is tempered by heightened awareness that higher education is a good investment, guaranteeing future earnings that will compensate shortterm spending (item g). These results are consistent with findings about immigrants' social 
norms and beliefs about costs and benefits connected with investing in tertiary education in Italy (Albertini et al., 2018; Albertini and Semprebon, 2018). Other significant differences concern future job prospects: G1s and G2s place greater importance on luck than Italians do (item e), and G1s are more convinced than Italians that a degree is not necessary for finding an acceptable job (item k). Finally, G2s perceive university studies as more difficult than Italians do (item c).

A principal components analysis allows us to identify the perceptual map underlying these responses: Table 5 displays the items' loading on the first two extracted components, and Figure 1 shows the resulting map. ${ }^{10}$ In Figure 1, each item is represented by a black dot: dots that are near one another correspond to items towards which respondents express similar levels of approval (eg, those who believe that tuition fees are not, in comparative terms, a relevant factor in deciding whether to attend university also tend to believe that higher education involves cultural enrichment); dots that are far from one another correspond to items towards which individuals express diverging levels of support (eg, those who believe that a university degree does not help find a job tend to reject the idea that graduates' incomes offset costs of higher education).

\section{[Figure 1 here]}


The perceptual map lends itself to a straightforward interpretation. The right-hand section of the figure features items supporting pro-university choices; the left-hand section highlights reasons adduced to forgo higher education. The horizontal axis can thus be characterised simply, in terms of 'pro vs. con' attitudes toward higher education. The second component (vertical axis) juxtaposes items involving a denial of the link between university studies and employment (in the job market, luck and personal endorsements count more than education: upper quadrants) to others explicitly underlining the opportunity of cost-benefit analyses in evaluating whether to pursue higher education.

The centroids of selected subgroups provide additional insights. Figure 1 features the centroids (white dots) of school (sub)tracks. Students enrolled in the three academic subtracks are located in the upper right-hand quadrant; technical and vocational tracks are in the lower left-hand quadrant. So, as one shifts from vocational to academic (especially humanities) tracks, one observes a greater incidence of positions favourable to university education and job-sensitive decision-making.

Figures 2 and 3 show that Italian students tend to endorse pro-university items with greater intensity than immigrant-origin youths; G1s appreciate university education to a lesser degree and are more prone to cost-benefit considerations; G2s occupy an intermediate position between Italians and G1s. Within each of these groups, males and 
females are associated with appreciably different beliefs, and girls are less likely to emphasise cost-benefit analyses (Figure 2). Similarly, Figure 3 highlights how families' cultural resources exert a positive impact on the perception of the value of higher education; this tendency is less marked among G1s. The two components reflecting attitude towards higher education and perception of a link between higher education and job prospects will be used as intervening variables in the Section 6 models.

\section{[Figure 2 here]}

\section{[Figure 3 here]}

\section{Higher Education Intentions}

Once students reach the end of upper secondary education, they need to address the question of whether to continue studying at the university level. Although such choices, especially if they are mere statements of intent, are reversible, respondents, on the whole, seem to have clear ideas about their future: only a small minority $(9.5 \%)$ is unable to express an opinion, and over two-thirds intend to continue their studies (Table 6). G2s and, especially, G1s are less likely to engage in higher education; G1s are more likely to qualify their plans ('probably' rather than 'certainly'). Immigrant-origin youths are also slightly more liable to admit to uncertainty in more general terms ('don't know'). 
A set of binomial logistic regression models was developed in which the dependent variable has two values: the reference category comprises respondents not intending to enrol at university and those who 'don't know'; the other category comprises respondents 'certainly' or 'probably' intending to enrol at university. The models illustrated in Table 7, besides the two main explanatory variables (Italian/immigrant status and school track), accommodate increasingly wider, incremental covariate sets.

Model 1 focuses on Italian/immigrant status and school track as explanatory variables and gender, parental occupational class and parental education as control variables; it also includes an interaction effect among the first two variables, since immigrant status and school tracks are closely linked (Table 1). The likelihood of pursuing university education is significantly higher among individuals with well-educated parents, with upper- or middle-class backgrounds, attending the academic track, and girls. Immigrant-origin youths display a significantly stronger intention (compared to Italians, other variables being equal) to enrol at university if they currently attend a vocational school, whereas they are less inclined to pursue higher education if they are in academically-oriented schools. On the whole, school track and general social origin factors exert significant influence on schoolleavers' education intentions. 
Model 2 incorporates school performance variables, respondents' self-image and parental support for schooling. Almost all of these additional variables display a significantly positive effect on the intention to pursue higher education and appreciably improve the model's predictive power. Gender, however, no longer emerges as a significant influence; and the effect of G1 status weakens appreciably.

It is reasonable to expect variables more tightly connected to higher education to mediate the preceding covariates' effect on tertiary education intentions. Model 3 includes friends' and parental support for university and the tendency to reject/accept the link between higher education and the job market. These additional variables are all significantly and positively linked to the intention to earn a tertiary qualification. A few other variables (primarily parental education and parental support for schooling) see their effects lose statistical significance. In particular, immigrant status relinquishes its role as a significant explanatory variable. Current school track effects weaken slightly but remain significant. Model 3's predictive power further increases with respect to Model 2's.

Finally, Model 4 adds favourable attitude towards higher education. This addition is to a certain degree redundant: one would reasonably expect a robust association between beliefs in university's benefits and decisions to partake in them. In fact, Model 4 features a higher level of predictive power, with a significant positive effect of the newly inserted 
variable. More interestingly, perhaps, we may focus on the effects of the explanatory variables. Firstly, school track continues to wield a strong effect, even after controlling for all other variables: attending a liceo, rather than a vocational institute, greatly increases the likelihood of seeking a university degree among Italians. G1s and G2s are similar to Italians in their intention to enrol at university.

In order to focus on the differences among Italians, G1s and G2s, one may examine the predicted probabilities of these groups' intentions to continue studying at the tertiary level (Figure 4). ${ }^{11}$ It is quite clear that the more marked differences involve school tracks: within each track there is no significant variation in university intentions between Italians, G2s and G1s; accordingly, within each Italian or immigrant group, students in academic tracks are significantly more likely to pursue higher education than their peers in technical or vocational schools. Nor are significant differences observed, within each track, between G1s and G2s. It is interesting to note, however, that in vocational schools, G1s and, especially, G2s $(\alpha<0.10)$ express stronger higher intentions than Italians do. ${ }^{12}$

These findings support the idea that subsequent selective processes result in comparatively high levels of homogeneity among native and immigrant-origin students as they near completion of their upper secondary education. In other words, at that comparatively advanced point of their educational careers G1s and G2s are quite similar to 
Italians. Differing propensity to enrol in tertiary education stems not from cultural or geographical origin - nor from other unobserved characteristics - but from the decision students took five years earlier, when they (and their families) opted for an academic, technical or vocational track.

\section{Concluding Remarks}

This article has focused on a rarely studied population: immigrant-origin youths who are on the verge of completing upper secondary education in Italy. Our respondents are not representative of immigrant-origin youths in general, for the former have survived social and school selection mechanisms that could plausibly reduce the disadvantages that typically plague G1s and G2s. Findings highlight that, even at the end of their school careers, immigrant-origin youths disproportionately attend non-academic tracks and belong to socially underprivileged families; their parents, however, feature strong educational credentials. Immigrant-origin youths have had relatively weak accomplishment levels in the past, but in their final school year have largely closed the gap with respect to their Italian peers and have a comparable self-image as regards education. G1s and G2s receive less parental support than their Italian peers in terms of information exchange, but also enjoy greater encouragement in pursuing higher education. Immigrant-origin youths are 
comparatively more likely to hold critical views of higher education and are more sensitive to cost considerations when contemplating further learning efforts. A distinct gender difference is observed among both Italians and immigrant-origin students: males are more prone than females to perceive a link between higher education and job prospects.

The intention to enrol at university is comparatively weaker among G2s and, especially, G1s. Yet, as shown in Section 6, once other important characteristics are accounted for, G1s and G2s' likelihood of pursuing higher education does not differ from Italians'. Social origins, academic performance, support among parents and friends, and attitudes toward higher education exert more significant effects than immigrant origins do.

School track also significantly and independently affects stated intentions, suggesting that weaker tertiary education aspirations among immigrant-origin youths may be appreciably affected by early selection mechanisms that permeate the transition from lower to upper secondary education and their ensuing higher concentration in non-academic tracks. On the one hand, Italian upper secondary schools differ (obviously) from comprehensive systems, in that the former feature a track structure with persistently distinct social and performance profiles. On the other hand - unlike systems relying on binding mechanisms for sorting students into tracks - Italian schools place no formal constraints on families' decisions. This hybrid arrangement may help explain why immigrant-origin 
students' choices in Italy differ from those observed in other countries. Achieving a higher university transition rate among immigrant-origin youths would thus seem to suggest greater effort in guidance and orientation activities, and other appropriate 'nudges', geared to inducing such students, and their parents, to undertake more demanding upper secondary school tracks. Of course, such choices also need to be supported by teachers, who on the contrary often (and successfully) discourage underprivileged youths, including those of immigrant origin, from enrolling in academic tracks even when they are good students (Romito 2016). 


\section{Notes}

* The authors thank the guest editor and an anonymous reviewer for their comments.

${ }^{1}$ An alternative option to these tracks are vocational training courses (istruzione $e$ formazione professionale), which typically last for 3 years, are even more oriented to the labour market, and provide no access to higher education. These programmes allow some youths to fulfil an ambiguous 'right/duty' which in 2007 extended 'compulsory education and training' from 8 to 10 years.

${ }^{2}$ After completing lower secondary education, youths can also decide to enrol in vocational training programmes that are regulated by regional authorities and not part of the school system; such programmes account for about 1 in 10 youths in education or training and feature a relatively high incidence of non-Italians.

3 The cited figures may contain 'noise' deriving from the fact that over the last few years vocational schools have phased out three-year certificates; the decrease in foreign-origin youths in the older cohorts might be due to the fact that they enrolled in these schools precisely in order to earn such a certificate and did so without actually 'dropping out'.

${ }^{4}$ The larger project, 'Social memberships, education and beliefs par-participation at the university: an integrated experiment with longitudinal survey', was financed by the Ministry of Education, University and Research (PRIN 2010-11, grant no. 2010EE499R_004) and carried out by research units at the universities of Trento. Milan: Bologna and Salerno. A comprehensive overview of the project's goals, conceptual framework and method is provided by Abbiati et al. 2016.

The original study was also carried out in the province of Salerno and thus involved a total of over 9,000 students. Since Salerno (with only 33 immigrant-origin youths) contributed data almost exclusively to the native subsample and is located in Southern Italy, it was left out of our analysis in order to reinforce its comparative rationale (see also Note $6)$.

${ }^{5}$ Children of mixed couples, immigrant-origin youths from developed Western countries, and respondents with missing values on the variables considered in this article were discarded. Our reference sample thus comprises 5,646 units, of which 525 of immigrant origin.

${ }^{6}$ Milan, Vicenza, and Bologna are located in the more economically developed Northern part of Italy, featuring better employment opportunities, superior educational contexts (as repeatedly documented in PISA studies), as well as higher levels of foreign-origin students 
(14.4, 13.8 and $15.1 \%$ of the school population in 2014/15, respectively) with respect to the South (2.9\% in Salerno, the province excluded from our study). Compared to Bologna and Milan, the Vicenza subsample features a slightly higher incidence of less educated parents and lower class families.

${ }^{7}$ Open-ended answers to items eliciting parental employment status were coded according to a simplified EGP (Erikson-Goldthorpe-Portocarero) class scheme. The parent with the highest status determined respondents' placement into one of four classes. 'Upper' includes entrepreneurs, managers and practitioners of liberal professions; 'white collar middle' comprises non-manual higher- or medium-grade workers; 'self-employed' include small employers who carry out manual work in their businesses; manual and lower-grade non-manual workers belong to 'working'.

${ }^{8}$ Migrants in Italy have comparatively low educational credentials. Italy, along with Greece and Slovenia, reports the lowest rate of tertiary educational attainment among its 25/64-year-old foreign-born population (less than 15\%). Accordingly, Italy features the highest share of non-EU-born residents having attained at most lower secondary education (51\%) (Eurostat Migrant integration statistics: http://ec.europa.eu/eurostat/statisticsexplained/index.php/Migrant_integration_statistics__education\#Highest_educational_attainment).

${ }^{9} \mathrm{G} 2 \mathrm{~s}$ ' area of origin is defined by parents' country of birth; if parents come from two different countries, the father's birthplace determines area of origin.

${ }^{10}$ Initial scores were replaced by their deviations from each respondent's mean score, calculated on a case-by-case basis across all items. The resulting values were submitted to a principal components analysis; the first two components account, respectively, for 25.3 and $13.0 \%$ of total variance. No axis rotation was implemented.

${ }^{11}$ Probabilities were estimated using the 'margins' procedure and its 'over' and 'atmeans' options in the Stata statistical software package.

${ }^{12}$ As a robustness check, we also ran separate models - including all of Model 4's covariates (results available upon request) - and estimated corresponding predicted probabilities for each of the school tracks. The results reflect those reported in Table 7 and Figure 4 and, in particular, do not identify any significant effects tied to Italian/immigrant status. Within vocational schools, however, consistently with Model 4, G2s display a higher propensity $(\alpha<0.10)$ to enroll in university. 


\section{References}

Abbiati G, Barone C, Argentin G and Schizzerotto A (2016) Information matters, but it is not enough: a field experiment on the causal effect of information barriers for participation in higher education. FBK-IRVAPP Working Paper No. 2016-11. Trento: FBK-IRVAPP.

Alba R (2004) Language Assimilation Today: Bilingualism Persists more than in the Past, But English Still Dominates. Lewis Mumford Center for Comparative Urban and Regional Research, University of Albany.

Albertini M, Gasperoni G and Mantovani D (2018) Whom to help and why? Family norms on financial support for adult children among immigrants. Journal of Ethnic and Migration Studies, forthcoming.

Albertini M and Semprebon M (2018) A burden to the welfare state? Expectations of non-EU migrants on welfare support in Northern Italy, Journal of European Social Policy, forthcoming.

Azzolini D (2014) Come vanno a scuola I figli degli immigrati? Gli apprendimenti nella scuola primaria italiana. In: Colombo A (ed) Figli, lavoro, vita quotidiana. Bologna: Il Mulino, pp. 73-104.

Azzolini D, Schnell P and Palmer JR (2012) Educational Achievements Gaps between Immigrant and Native Students in Two 'New' Immigration Countries: Italy and Spain in Comparison. Annals of the American Academy of Political and Social Science (643)1: 46-77.

Ballarino G and Checchi D (eds) (2006) Sistema scolastico e disuguaglianza sociale. Scelte individuali e vincoli strutturali. Bologna: Il Mulino.

Barabanti P (2016) Apprendimenti e gap territoriali. Una comparazione fra studenti italiani e stranieri: In: Santagati M and Ongini V (eds) Alunni con cittadinanza non italiana. La scuola multiculturale nei contesti locali. Milan: Fondazione ISMU, pp. 109-135.

Bertozzi R (2016) Transizioni e scelte formative. Opportunità per gli allievi stranieri nelle diverse aree territoriali. In: Santagati M and Ongini V (eds) Alunni con cittadinanza non italiana. La scuola multiculturale nei contesti locali. Milan: Fondazione ISMU, pp. 81-108.

Bottani N (1986) La ricreazione è finita. Bologna: Il Mulino.

Bowen H (1997) Investment in Learning: The Individual and Social Value of American Higher Education. Baltimore: Johns Hopkins University, 2nd ed.

Breen R and Goldthorpe JH (1997) Explaining Educational Differentials: Towards a Formal Rational Action Theory. Rationality and Society (9)3: 275-305.

Brinbaum Y and Cebolla-Boado H (2007) The School Careers of Ethnic Minority Youth in France: Success or Disillusion? Ethnicities (7)3: 445-474.

Caplan N, Choy MH and Whitmore JK (1991) Children of the Boat People: A Study of Educational Success. Ann Arbor: University of Michigan Press.

Casacchia O, Natale N, Paterno A and Terzera L (eds) (2008) Studiare insieme, crescere insieme? Un'indagine sulle seconde generazioni in dieci regioni italiane. Milan: Franco Angeli

Colussi E and Ongini V (2016) Quadro generale sugli alunni con cittadinanza non italiana. In: Santagati M and Ongini V (eds) Alunni con cittadinanza non italiana. La scuola multiculturale nei contesti locali. Milan: Fondazione ISMU, pp. 17-44.

Dalla Zuanna G, Farina P and Strozza S (2009) Nuovi italiani. I giovani immigrati cambieranno il nostro paese? Bologna: Il Mulino.

Di Bartolomeo A (2011) Explaining the Gap in Educational Achievement between Second-Generation Immigrants and Natives: The Italian Case. Journal of Modern Italian Studies (16)4: 437-449.

Gambetta D (1987) Were They Pushed or Did They Jump? Individual Decision Mechanism in Education. Cambridge: Cambridge University Press. 
Gasperoni G (1996) Diplomati e istruiti. Rendimento scolastico e istruzione secondaria superiore in Italia. Bologna: Il Mulino.

Gasperoni G (2008) Le scelte scolastiche. I vissuti degli studenti del III anno della scuola secondaria di I grado e delle loro famiglie: In: ISFOL (ed) La domanda di istruzione e formazione degli allievi in dirittodovere all'istruzione e formazione. Rome: ISFOL, pp. 29-97.

Kao G e Tienda M (1995) Optimism and Achievement: The Educational Performance of Immigrant Youth. Social Science Quarterly (76)1: 1-19.

Kao G e Tienda M (1998) Educational Aspirations of Minority Youth. American Journal of Education (106)3: 349-384.

Kristen C and Granato N (2007) The Educational Attainment of the Second Generations in Germany. Ethnicities (7)3: 343-366.

Kristen C, Reimer D and Kogan I (2008) Higher Education Entry of Turkish Immigrant Youth in Germany. International Journal of Comparative Sociology (49)2-3: 127-151.

Lagomarsino F and Ravecca A (2014) Il passo seguente. I giovani di origine straniera all'università. Milan: Franco Angeli.

Mantovani D (2008) Seconde generazioni all'appello. Studenti stranieri e istruzione secondaria superiore a Bologna. Bologna: Istituto Cattaneo.

Mantovani D (2011) Ritardo e ripetenza scolastica fra gli studenti stranieri nella provincia di Bologna. In Barbagli M and Schmoll C (eds) Stranieri in Italia. La generazione dopo. Bologna: Il Mulino, pp. 149-195.

Mantovani D and Martini E (2008) Children of Immigrants in Trento: Educational Achievement through the Lens of Friendship. Intercultural Education (19)5: 435-447.

Mare, RD (1980) Social Background and School Continuation Decisions. Journal of the American Statistical Association (75): 295-305.

MIUR - Ministero dell'Istruzione, dell'Università e della Ricerca (2005) Indagine sugli esiti degli alunni con cittadinanza non italiana. Anno scolastico 2003-2004. Rome: MIUR.

MIUR (2008) Alunni con cittadinanza non italiana. Scuole statali e non statali. Anno scolastico 2006/2007, Roma.

MIUR (2015) Notiziario. Gli alunni stranieri nel sistema scolastico italiano. A.s. 2014/15. Rome: MIUR.

OECD (2006) Where Immigrant Students Succeed. A Comparative Review of Performance and Engagement in PISA 2003. Paris: OECD.

Portes A e Hao L (2002) The Price of Uniformity: Language, Family and Personality Adjustment in the Immigrant Second Generation. Ethnic and Racial Studies (25)6: 889-912.

Portes A e Rumbaut, RG (2001a) Legacies: The Story of the Immigrant Second Generation. Berkeley: University of California Press

Portes A e Rumbaut, RG (2001b) Ethnicities: Children of Immigrants in America. Berkeley: University of California Press.

Portes A e Rumbaut, RG (2006) Immigrant America: A Portrait. Berkeley: University of California Press, 3rd ed.

Rea A, Wrench J and Ouali N (1999) Introduction: Discrimination and Diversity. In: Wrench J, Rea A and Ouali N (eds) Migrants, Ethnic Minorities and the Labour Market. Integration and Exclusion in Europe. London-New York: Macmillan, pp. 1-18.

Romito M (2016) I consigli orientativi agli studenti di origine straniera nella scuola secondaria di primo grado. Un caso a parte? Rivista italiana di sociologia (57)1: 31-54. 
Rumbaut RG (1994) The Crucible Within: Ethnic Identity, Self-Esteem and Segmented Assimilation among Children of Immigrants. International Migration Review (28): 748-794.

Rumbaut RG (1997) Assimilation and Its Discontents: Between Rhetoric and Reality. International Migration Review (31)4: 923-960.

Vallet LA and Caille JP (1999) Migration and Integration in France: Academic Careers of Immigrants' Children in Lower and Upper Secondary School. In: ESF Conference on Migration and Inter-Ethnic Relations in Europe, Obernai, 23-28 September.

Vargas JH (2004) College Knowledge: Addressing Information Barriers to College. Boston: College Access Services-Education Resources Institute.

Vergolini L and Vlach E (2017) Family Background and Educational Path of Italian Graduates. Higher Education (73)2: 245-259. 
Table 1. Socio-demographic characteristics by Italian/immigrant status (\% values)

\begin{tabular}{lcccc}
\hline & Italian & G2 & G1 & Total \\
\hline School (sub)track & & & & \\
$\quad$ Academic: humanities & 7.4 & 0.0 & 0.7 & 6.7 \\
$\quad$ Academic: science & 26.1 & 16.9 & 11.1 & 25.0 \\
$\quad$ Academic: other & 15.7 & 13.9 & 9.4 & 15.3 \\
$\quad$ Technical & 34.8 & 38.8 & 41.3 & 35.3 \\
$\quad$ Vocational & 16.0 & 30.4 & 37.5 & 17.7 \\
Total & 100 & 100 & 100 & 100 \\
\hline Gender & & & & \\
Male & 48.2 & 45.1 & 47.9 & 48.1 \\
Female & 51.8 & 54.9 & 52.1 & 51.9 \\
\hline Age (mean) & 18.3 & 18.6 & 19.3 & 18.4 \\
\hline Years in Italy (mean) & - & 17.6 & 9.2 & - \\
\hline Parents' occupational class & & & & \\
$\quad$ Upper class & 23.7 & 8.9 & 5.6 & 22.2 \\
$\quad$ Middle white collar & 42.4 & 12.7 & 16.3 & 39.7 \\
$\quad$ Self-employed & 14.3 & 21.5 & 11.8 & 14.5 \\
$\quad$ Working & 19.6 & 56.9 & 66.3 & 23.6 \\
\hline Parents' education & & & & \\
$\quad$ < Upper secondary & 29.4 & 33.8 & 34.7 & 29.9 \\
$\quad$ Upper secondary & 39.1 & 30.0 & 28.8 & 38.1 \\
$\quad$ Higher education & 31.5 & 36.2 & 36.5 & 32.0 \\
\hline Area of origin & & & & \\
$\quad$ Eastern Europe & & 23.0 & 49.1 & \\
$\quad$ Africa & & 30.6 & 11.5 & \\
$\quad$ Asia & & 13.2 & 17.1 & \\
$\quad$ Central-South America & $(5,121)$ & $(237)$ & $(288)$ & $(5,676)$ \\
\hline (N) & & & & \\
\hline
\end{tabular}


Table 2. School performance (\% values; mean for final year marks) and self-image (1-10 scale: percentage of respondents expressing a score between 8 and 10, mean score and, in parentheses, standard deviation) by Italian/immigrant status

\begin{tabular}{lcccc}
\hline & Italian & G2 & G1 & Total \\
\hline Final result of lower secondary school-leaving & exam & & & \\
Excellent & 13.4 & 4.2 & 10.8 & 12.8 \\
Very good & 42.2 & 38.4 & 34.7 & 41.8 \\
Good & 30.0 & 40.5 & 38.9 & 30.9 \\
Satisfactory & 14.4 & 16.9 & 15.6 & 14.5 \\
Total & 100 & 100 & 100 & 100 \\
\hline Regularity of school career & 44.9 & 28.9 & 33.9 & 43.7 \\
Regular career & 32.9 & 29.4 & 26.9 & 32.4 \\
Conditional promotion (at least & 22.2 & 41.7 & 39.2 & 23.9 \\
$\quad$ once) & 100 & 100 & 100 & 100 \\
Held back (at least once) & & & & \\
Total & & & & \\
\hline
\end{tabular}

Current year marks (1-10 scale; $6=$ lowest passing mark; standard deviation in parentheses)

\begin{tabular}{|c|c|c|c|c|}
\hline Maths & $6.7(1.3)$ & $6.5(1.2)$ & $6.7(1.2)$ & $6.7(1.3)$ \\
\hline Italian & $6.9(1.0)$ & $6.8(0.9)$ & $6.6(0.9)$ & $6.9(1.0)$ \\
\hline 2-subject mean & $6.8(0.9)$ & $6.6(0.9)$ & $6.6(0.9)$ & $6.8(0.9)$ \\
\hline \multicolumn{5}{|c|}{ Amount of time devoted to schoolwork at home, on a daily basis } \\
\hline Less than 1 hour & 20.5 & 20.7 & 19.1 & 20.4 \\
\hline 1-2 hours & 36.0 & 43.0 & 43.0 & 36.7 \\
\hline More than 2 hours & 43.5 & 36.3 & 37.9 & 42.9 \\
\hline Total & 100 & 100 & 100 & 100 \\
\hline \multicolumn{5}{|c|}{ Aptitude self-image: 'How strong is your aptitude for school?' (1-10 scale) } \\
\hline$\%$ reporting score of 8,9 or 10 & 38.1 & 37.7 & 36.6 & 38.0 \\
\hline Mean (and std. dev.) & $6.8(1.7)$ & $6.9(1.4)$ & $7.0(1.5)$ & $6.8(1.7)$ \\
\hline \multicolumn{5}{|c|}{ Attitude self-image: 'How much do you like going to school?' (1-10 scale) } \\
\hline$\%$ reporting score of 8,9 or 10 & 27.0 & 24.8 & 31.7 & 27.1 \\
\hline Mean (and std. dev.) & $6.2(2.0)$ & $6.5(1.7)$ & $6.6(1.8)$ & $6.3(1.9)$ \\
\hline $\begin{array}{l}\text { School self-image index (1-10 } \\
\text { scale): mean (and std. dev.) }\end{array}$ & $\begin{array}{c}6.5 \\
(1.6)\end{array}$ & $\begin{array}{c}6.7 \\
(1.3)\end{array}$ & $\begin{array}{c}6.8 \\
(1.4)\end{array}$ & $\begin{array}{c}6.5 \\
(1.6)\end{array}$ \\
\hline
\end{tabular}

Note: The school self-image index is the mean of the two answers given to the aptitude and attitude self-image items. 
Table 3. Parental support for schooling, by Italian/immigrant status: share of respondents stating that the listed event occurs 'very often' (\% values)

\begin{tabular}{lcccc}
\hline & Italian & G2 & G1 & Total \\
\hline $\begin{array}{l}\text { a. My parents ask me about by school day } \\
\text { b. My parents help me if I have problems } \\
\quad \text { at school }\end{array}$ & 53.2 & 27.9 & 31.4 & 51.1 \\
$\begin{array}{l}\text { c. I talk with my parents about what I will } \\
\quad \text { do after completing school }\end{array}$ & 27.4 & 21.5 & 22.0 & 26.9 \\
$\begin{array}{l}\text { Parental support for school index (1-4 } \\
\text { scale): mean (and std. dev.) }\end{array}$ & 2.8 & 2.4 & 2.4 & 2.8 \\
\hline
\end{tabular}

Note: Items a, b and c use a four-point scale, coded 1 to 4: never or almost never / occasionally / often / very often. The parent support index is the mean of three answers. 
Table 4. Support for higher education among family and friends, by Italian/immigrant status (1-10 scale: percentage of respondents expressing a score between 8 and 10, mean score and, in parentheses, standard deviations)

\begin{tabular}{|c|c|c|c|c|}
\hline & Italian & G2 & G1 & Total \\
\hline \multicolumn{5}{|c|}{ a. Most of my friends are enrolled / will enrol in a university programme } \\
\hline$\%$ reporting score of 8,9 or 10 & 43.6 & 27.9 & 20.5 & 41.7 \\
\hline Mean (and std. dev.) & $6.5(2.6)$ & $5.7(2.6)$ & $5.1(2.6)$ & $6.4(2.6)$ \\
\hline \multicolumn{5}{|c|}{ b. My friends are a source of useful information about university education } \\
\hline$\%$ reporting score of 8,9 or 10 & 24.4 & 20.8 & 15.6 & 23.8 \\
\hline Mean (and std. dev.) & $5.4(2.6)$ & $5.3(2.5)$ & $4.6(2.6)$ & $5.3(2.6)$ \\
\hline \multicolumn{5}{|c|}{ c. My parents and relatives are a source of useful information about university education } \\
\hline$\%$ reporting score of 8,9 or 10 & 22.8 & 16.5 & 11.1 & 21.9 \\
\hline Mean (and std. dev.) & $5.2(2.6)$ & $4.5(2.6)$ & $4.2(2.3)$ & $5.1(2.6)$ \\
\hline \multicolumn{5}{|c|}{ d. My parents feel that it is important that I enrol in a university programme } \\
\hline$\%$ reporting score of 8,9 or 10 & 45.7 & 53.6 & 56.6 & 46.6 \\
\hline Mean (and std. dev.) & $6.6(2.8)$ & $7.4(2.6)$ & $7.4(2.7)$ & $6.7(2.8)$ \\
\hline $\begin{array}{l}\text { Friends' support for higher } \\
\text { education (1-10 scale): mean } \\
\text { (and std. dev.) }\end{array}$ & $\begin{array}{c}6.0 \\
(2.3)\end{array}$ & $\begin{array}{c}5.5 \\
(2.3)\end{array}$ & $\begin{array}{c}4.8 \\
(2.3)\end{array}$ & $\begin{array}{c}5.9 \\
(2.3)\end{array}$ \\
\hline $\begin{array}{l}\text { Parental support for higher } \\
\text { education (1-10 scale): mean } \\
\text { (and std. dev.) }\end{array}$ & $\begin{array}{c}5.9 \\
(2.2)\end{array}$ & $\begin{array}{c}5.9 \\
(2.1)\end{array}$ & $\begin{array}{c}5.8 \\
(2.1)\end{array}$ & $\begin{array}{c}5.9 \\
(2.2)\end{array}$ \\
\hline
\end{tabular}

Note: The friends' support index is the mean of the two answers given to items a and b; the parental support index is the mean of the two answers given to items $\mathrm{c}$ and $\mathrm{d}$. 
Table 5. Levels of approval for items about the relationship between higher education and job opportunities, by Italian/immigrant status (on 1-10 scale, mean values), and loadings on components extracted via principal components analysis (see Figure 1)

\begin{tabular}{|c|c|c|c|c|c|c|}
\hline & \multirow[t]{2}{*}{ Italian } & \multirow[t]{2}{*}{$\mathrm{G} 2$} & \multirow[t]{2}{*}{ G1 } & \multirow[t]{2}{*}{ Total } & \multicolumn{2}{|c|}{$\begin{array}{l}\text { Loadings on } \\
\text { component: }\end{array}$} \\
\hline & & & & & 1 & 2 \\
\hline $\begin{array}{l}\text { a. What I learn at university is useful for } \\
\text { my cultural enrichment }\end{array}$ & $\begin{array}{c}8.6 \\
(1.6)\end{array}$ & $\begin{array}{c}8.6 \\
(1.6)\end{array}$ & $\begin{array}{c}8.5 \\
(1.6)\end{array}$ & $\begin{array}{c}8.6 \\
(1.6)\end{array}$ & +0.536 & +0.095 \\
\hline $\begin{array}{l}\text { b. To find a good job in Italy, personal } \\
\text { endorsements count more than a } \\
\text { university degree }\end{array}$ & $\begin{array}{l}7.1 \\
(2.3)\end{array}$ & $\begin{array}{c}7.2 \\
(2.1)\end{array}$ & $\begin{array}{l}7.0 \\
(2.3)\end{array}$ & $\begin{array}{c}7.1 \\
(2.2)\end{array}$ & -0.053 & +0.542 \\
\hline c. University studies are very difficult & $\begin{array}{l}6.8 \\
(1.9)\end{array}$ & $\begin{array}{c}7.1 \\
(1.9)\end{array}$ & $\begin{array}{c}7.0 \\
(2.0)\end{array}$ & $\begin{array}{c}6.9 \\
(1.9)\end{array}$ & +0.176 & -0.360 \\
\hline $\begin{array}{l}\text { d. University graduates have more } \\
\text { opportunities than upper secondary } \\
\text { diploma-holders to find good jobs }\end{array}$ & $\begin{array}{l}6.6 \\
(2.3)\end{array}$ & $\begin{array}{l}6.8 \\
(2.1)\end{array}$ & $\begin{array}{c}6.7 \\
(2.3)\end{array}$ & $\begin{array}{c}6.6 \\
(2.3)\end{array}$ & +0.745 & -0.067 \\
\hline $\begin{array}{l}\text { e. In today's world finding a good job is } \\
\text { a matter of luck }\end{array}$ & $\begin{array}{l}6.1 \\
(2.2)\end{array}$ & $\begin{array}{c}6.9 \\
(1.9)\end{array}$ & $\begin{array}{l}6.5 \\
(2.3)\end{array}$ & $\begin{array}{l}6.1 \\
(2.2)\end{array}$ & -0.126 & +0.673 \\
\hline $\begin{array}{l}\text { f. For me, attending university would } \\
\text { mean having to wait too long to earn } \\
\text { my own income }\end{array}$ & $\begin{array}{l}5.3 \\
(2.7)\end{array}$ & $\begin{array}{c}6.0 \\
(2.4)\end{array}$ & $\begin{array}{c}6.2 \\
(2.6)\end{array}$ & $\begin{array}{c}5.4 \\
(2.7)\end{array}$ & -0.618 & -0.346 \\
\hline $\begin{array}{l}\text { g. The costs of university studies are } \\
\text { amply compensated by graduates' } \\
\text { higher incomes }\end{array}$ & $\begin{array}{c}5.1 \\
(2.0)\end{array}$ & $\begin{array}{c}5.7 \\
(1.8)\end{array}$ & $\begin{array}{l}5.6 \\
(1.9)\end{array}$ & $\begin{array}{c}5.1 \\
(2.0)\end{array}$ & +0.606 & -0.279 \\
\hline $\begin{array}{l}\text { h. Studying at university would be too } \\
\text { expensive for me }\end{array}$ & $\begin{array}{c}4.4 \\
(2.5)\end{array}$ & $\begin{array}{c}5.7 \\
(2.6)\end{array}$ & $\begin{array}{c}6.4 \\
(2.4)\end{array}$ & $\begin{array}{c}4.6 \\
(2.5)\end{array}$ & -0.499 & -0.170 \\
\hline $\begin{array}{l}\text { i. Having a university degree does not } \\
\text { improve one's chances of finding a job }\end{array}$ & $\begin{array}{c}4.4 \\
(2.5)\end{array}$ & $\begin{array}{l}4.6 \\
(2.4)\end{array}$ & $\begin{array}{c}4.6 \\
(2.5)\end{array}$ & $\begin{array}{c}4.4 \\
(2.5)\end{array}$ & -0.564 & +0.377 \\
\hline $\begin{array}{l}\text { j. In deciding whether to enrol at } \\
\text { university, tuition fees aren't important } \\
\text { for me }\end{array}$ & $\begin{array}{c}4.2 \\
(2.5)\end{array}$ & $\begin{array}{l}4.0 \\
(2.7)\end{array}$ & $\begin{array}{c}3.3 \\
(2.3)\end{array}$ & $\begin{array}{c}4.1 \\
(2.5)\end{array}$ & +0.497 & +0.054 \\
\hline $\begin{array}{l}\text { k. I do not need a university degree to } \\
\text { find the job I want }\end{array}$ & $\begin{array}{c}3.8 \\
(2.8) \\
\end{array}$ & $\begin{array}{c}3.9 \\
(2.6) \\
\end{array}$ & $\begin{array}{c}4.2 \\
(2.7) \\
\end{array}$ & $\begin{array}{c}3.8 \\
(2.8) \\
\end{array}$ & -0.571 & -0.406 \\
\hline
\end{tabular}


Figure 1. Perceptual map concerning the relationship between higher education and job opportunities (principal components analysis)

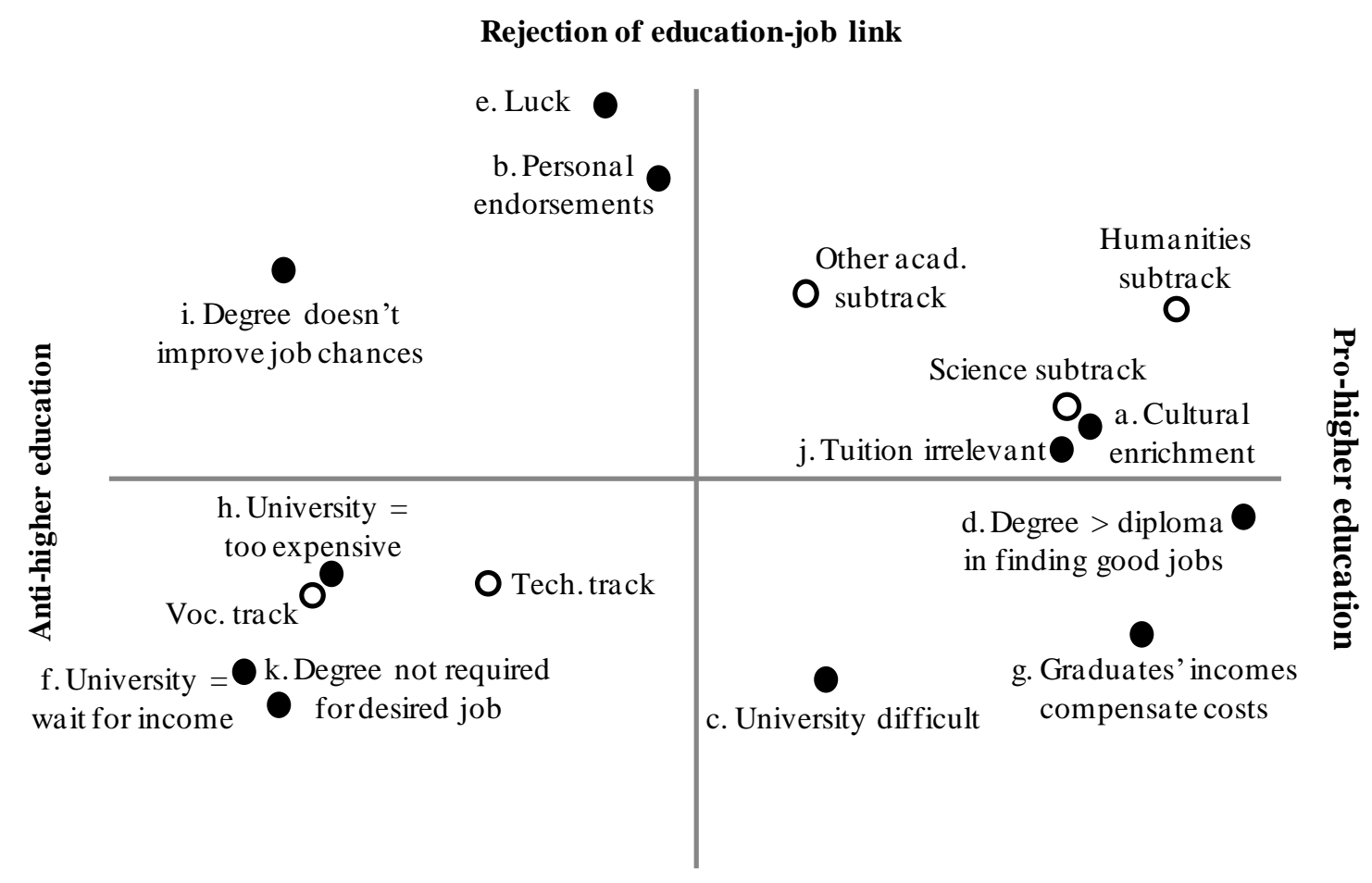

\section{Cost-benefit analysis}


Figure 2. Perceptual map concerning the relationship between higher education and job opportunities, with display of immigrant/Italian status and gender centroids

\section{Rejection of education-job link}

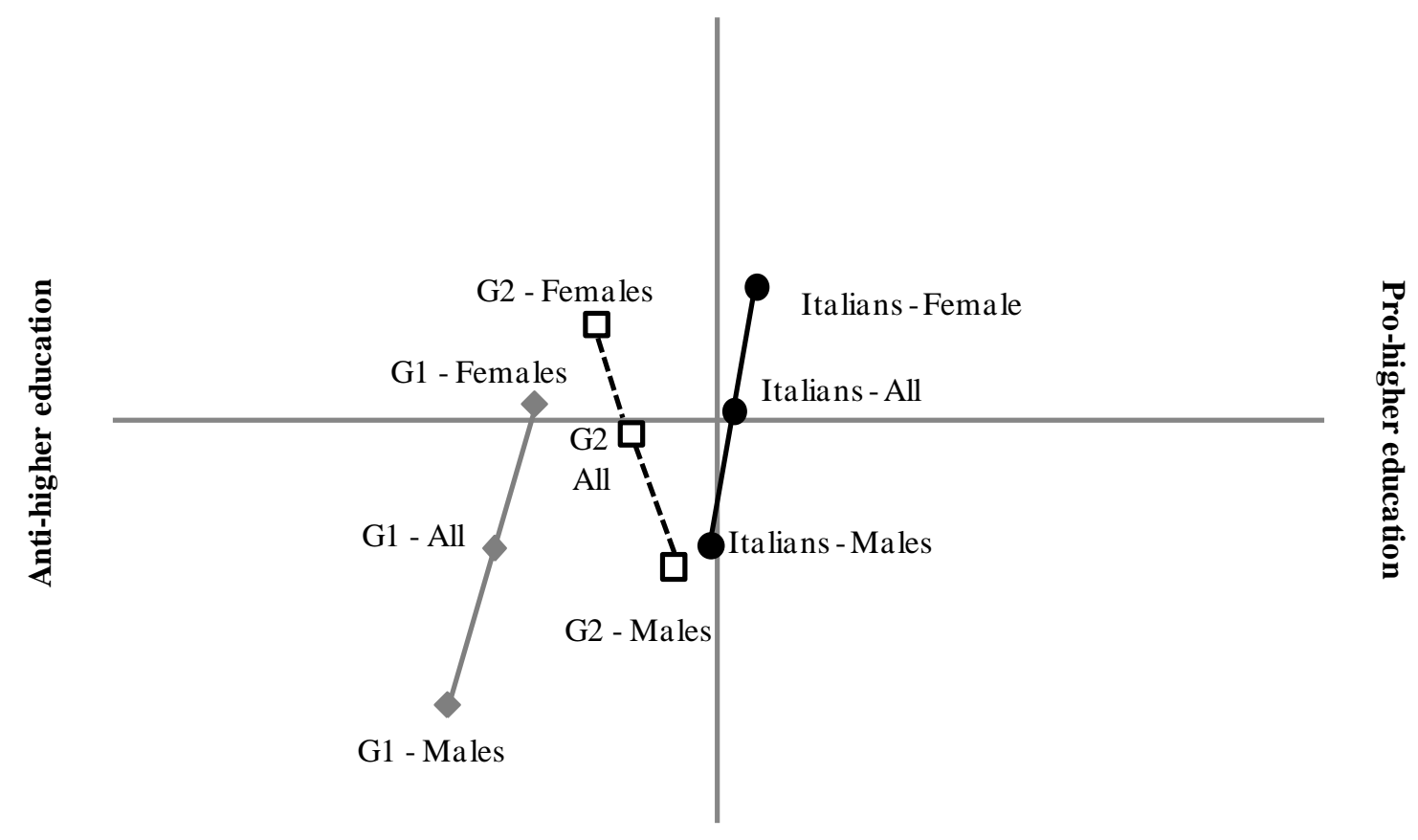

Cost-benefit analysis 
Figure 3. Perceptual map concerning the relationship between higher education and job opportunities, with display of immigrant/Italian status and parental education centroids

\section{Rejection education-job link}

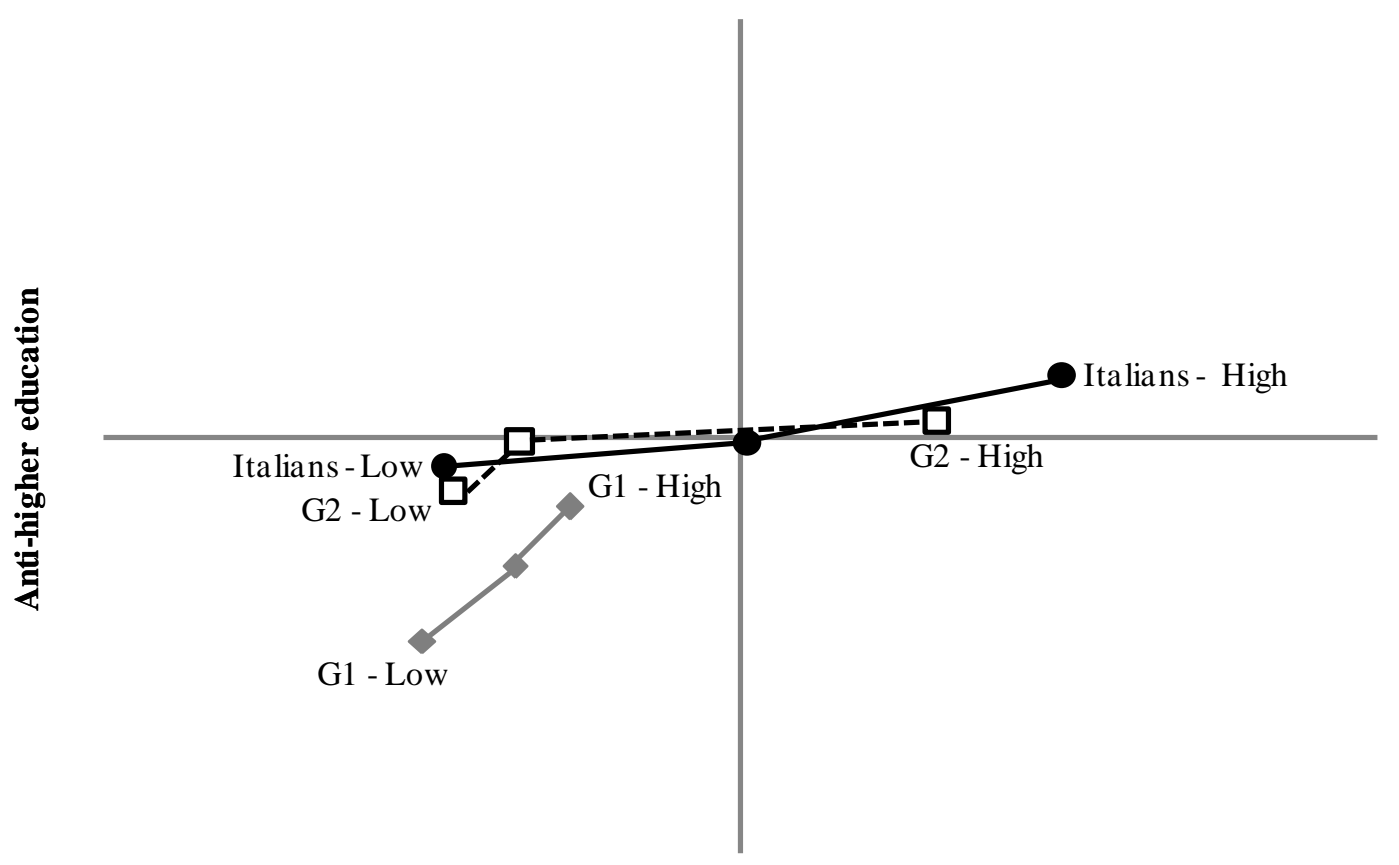

Cost-benefit analysis 
Table 6. Intention to enrol at university, by Italian/immigrant status (\% values)

\begin{tabular}{lcccc}
\hline & Italian & G2 & G1 & Total \\
\hline Certainly intends to continue & 37.7 & 33.8 & 20.1 & 36.6 \\
Probably intends to continue & 30.3 & 27.4 & 34.0 & 30.4 \\
Certainly + probably intends to continue & 68.0 & 61.2 & 55.1 & 67.0 \\
Does not intend & 23.0 & 25.3 & 31.0 & 23.5 \\
Does not know & 9.0 & 13.5 & 14.9 & 9.5 \\
& & & & \\
Total & 100 & 100 & 100 & 100 \\
\hline
\end{tabular}


Table 7. Binomial logistic regression models accounting for university enrolment (reference category: no higher education intentions) (regression coefficients; $N=5,646$ )

\begin{tabular}{|c|c|c|c|c|c|c|c|c|}
\hline & \multicolumn{2}{|c|}{ Model 1} & \multicolumn{2}{|c|}{ Model 2} & \multicolumn{2}{|c|}{ Model 3} & \multicolumn{2}{|c|}{ Model 4} \\
\hline & $\beta$ & S.e. & $\beta$ & S.e. & $\beta$ & S.e. & $\beta$ & S.e. \\
\hline Italian/immigrant status (ref. Italian) & & & & & & & & \\
\hline G2 & $+0.657^{* *}$ & 0.257 & $+0.659^{* *}$ & 0.275 & +0.428 & 0.293 & +0.608 & 0.325 \\
\hline G1 & $+0.466^{*}$ & 0.220 & +0.246 & 0.237 & +0.062 & 0.249 & +0.232 & 0.277 \\
\hline$\overline{\text { School track (ref. Vocational) }}$ & & & & & & & & \\
\hline Academic & $+3.059^{* * *}$ & 0.113 & $+2.923^{* * * *}$ & 0.132 & $+2.543^{* * *}$ & 0.139 & $+2.363^{* * *}$ & 0.153 \\
\hline Technical & $+0.670^{* * *}$ & 0.091 & $+0.568^{* * *}$ & 0.103 & $+0.495^{* * *}$ & 0.110 & $+0.438^{* * *}$ & 0.122 \\
\hline Italian/immigrant $\times$ School track & & & & & & & & \\
\hline G2-Academic & -0.833 & 0.483 & -0.982 & 0.503 & -0.641 & 0.534 & -0.906 & 0.577 \\
\hline G2-Technical & -0.547 & 0.336 & -0.455 & 0.359 & -0.456 & 0.379 & -0.763 & 0.417 \\
\hline G1-Academic & $-1.325^{* *}$ & 0.420 & $-1.201^{* *}$ & 0.456 & $-0.949^{*}$ & 0.468 & $-1.055^{*}$ & 0.502 \\
\hline G1-Technical & -0.228 & 0.291 & -0.016 & 0.313 & +0.081 & 0.328 & +0.057 & 0.367 \\
\hline$\overline{\text { Gender } \text { (ref. }=\text { male) }}$ & & & & & & & & \\
\hline Female & $+0.610^{* * *}$ & 0.070 & +0.087 & 0.085 & -0.044 & 0.092 & +0.136 & 0.103 \\
\hline Parental education (ref. < Upper sec.) & & & & & & & & \\
\hline Upper secondary & $+0.335^{* * *}$ & 0.085 & $+0.275^{* *}$ & 0.092 & +0.175 & 0.096 & +0.184 & 0.107 \\
\hline Post-secondary & $+0.553^{* * *}$ & 0.107 & $+0.510^{* * *}$ & 0.116 & +0.222 & 0.124 & +0.157 & 0.137 \\
\hline Occupational class (ref. Working) & & & & & & & & \\
\hline Upper class & $+0.837^{* * *}$ & 0.125 & $+0.960^{* * * *}$ & 0.137 & $+0.903^{* * *}$ & 0.145 & $+0.607^{* * *}$ & 0.161 \\
\hline Middle white collar & $+0.365^{* * *}$ & 0.096 & $+0.411^{* * *}$ & 0.104 & $+0.355^{* * *}$ & 0.109 & +0.221 & 0.121 \\
\hline Self-employed & $+0.275^{* *}$ & 0.105 & $+0.301^{* *}$ & 0.113 & +0.220 & 0.119 & +0.167 & 0.132 \\
\hline Lower sec. exam (ref. $\leq$ Good) & & & & & & & & \\
\hline Very good / excellent & & & +0.134 & 0.082 & +0.129 & 0.087 & +0.132 & 0.097 \\
\hline Current year marks (2-subject mean) & & & $+0.144^{* *}$ & 0.049 & $+0.176^{* * *}$ & 0.051 & $+0.269^{* * *}$ & 0.057 \\
\hline Daily schoolwork at home (ref. $<1 \mathrm{hr}$ ) & & & & & & & & \\
\hline $1-2$ hours & & & $+0.194^{*}$ & 0.097 & +0.178 & 0.102 & +0.132 & 0.114 \\
\hline More than 2 hours & & & $+0.487^{* * *}$ & 0.117 & $+0.468^{* * *}$ & 0.123 & $+0.409^{* *}$ & 0.138 \\
\hline School self-image & & & $+0.520^{* * *}$ & 0.030 & $+0.476^{* * *}$ & 0.031 & $+0.341^{* * *}$ & 0.034 \\
\hline Parental support for school & & & $+0.225^{* * *}$ & 0.056 & +0.024 & 0.060 & -0.020 & 0.067 \\
\hline Friends' support for higher education & & & & & $+0.051^{* *}$ & 0.019 & $+0.048^{* * *}$ & 0.021 \\
\hline Parental support for higher education & & & & & $+0.300^{* * *}$ & 0.021 & $+0.186^{* * *}$ & 0.024 \\
\hline Rejection HE-job link & & & & & $+0.472^{* * *}$ & 0.043 & $+0.659^{* * * *}$ & 0.049 \\
\hline Favourable attitude towards $H E$ & & & & & & & $+1.412^{* * * *}$ & 0.061 \\
\hline Constant & $-1.539^{* * *}$ & 0.108 & $-6.381^{* * *}$ & 0.368 & $-7.256^{* * *}$ & 0.399 & $-5.761^{* * * *}$ & 0.442 \\
\hline Pseudo $\mathrm{R}^{2}$ Cox and Snell & 0.297 & & 0.375 & & 0.416 & & 0.485 & \\
\hline Pseudo $\mathrm{R}^{2}$ Nagelkerke & 0.413 & & 0.522 & & 0.578 & & 0.675 & \\
\hline
\end{tabular}

${ }^{* * * *} \alpha<0.001 ;{ }^{* *} \alpha<0.01 ;{ }^{*} \alpha<0.05$ 
Figure 4. Predicted probabilities of university education intentions over school track and Italian/immigrant status, at mean values of other covariates in Model 4 (\% values and $95 \%$ confidence intervals)

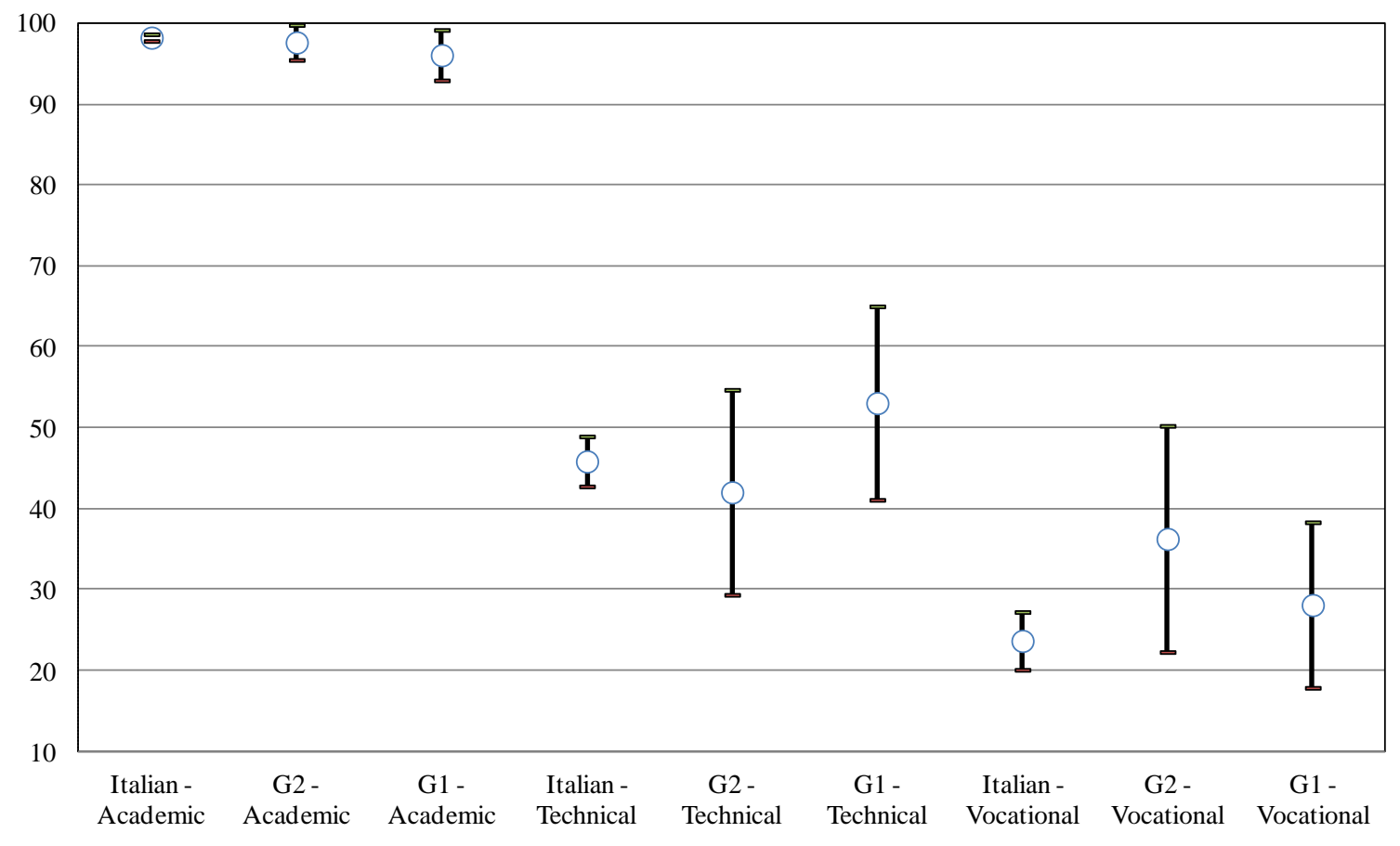

